\title{
Front Matter: Volume 9029
}

, "Front Matter: Volume 9029," Proc. SPIE 9029, Visual Information Processing and Communication V, 902901 (19 February 2014); doi: 10.1117/12.2062939

SPIE Event: IS\&T/SPIE Electronic Imaging, 2014, San Francisco, California, United SPIE. States 


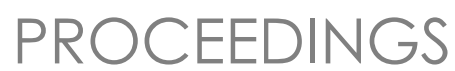

IS\&T / SPIE

Electronic

Imaging

SCIENCE AND TECHNOLOGY

\section{Visual Information Processing and Communication $\mathrm{V}$}

Amir Said

Onur G. Guleryuz

Robert L. Stevenson

Editors

5-6 February 2014

San Francisco, California, United States

Sponsored by

IS\&T-The Society for Imaging Science and Technology

SPIE

Published by

SPIE 
The papers included in this volume were part of the technical conference cited on the cover and title page. Papers were selected and subject to review by the editors and conference program committee. Some conference presentations may not be available for publication. The papers published in these proceedings reflect the work and thoughts of the authors and are published herein as submitted. The publishers are not responsible for the validity of the information or for any outcomes resulting from reliance thereon.

Please use the following format to cite material from this book:

Author(s), "Title of Paper," in Visual Information Processing and Communication $V$, edited by Amir Said, Onur G. Guleryuz, Robert L. Stevenson, Proceedings of SPIE-IS\&T Electronic Imaging, SPIE Vol. 9029, Article CID Number (2014)

ISSN: 0277-786X

ISBN: 9780819499462

Copublished by

SPIE

P.O. Box 10, Bellingham, Washington 98227-0010 USA

Telephone +1 3606763290 (Pacific Time) · Fax +1 3606471445

SPIE.org

and

IS\&T-The Society for Imaging Science and Technology

7003 Kilworth Lane, Springfield, Virginia, 22151 USA

Telephone +1 7036429090 (Eastern Time) · Fax +1 7036429094

imaging.org

Copyright (C) 2014, Society of Photo-Optical Instrumentation Engineers and The Society for Imaging Science and Technology.

Copying of material in this book for internal or personal use, or for the internal or personal use of specific clients, beyond the fair use provisions granted by the U.S. Copyright Law is authorized by the publishers subject to payment of copying fees. The Transactional Reporting Service base fee for this volume is $\$ 18.00$ per article (or portion thereof), which should be paid directly to the Copyright Clearance Center (CCC), 222 Rosewood Drive, Danvers, MA 01923. Payment may also be made electronically through CCC Online at copyright.com. Other copying for republication, resale, advertising or promotion, or any form of systematic or multiple reproduction of any material in this book is prohibited except with permission in writing from the publisher. The CCC fee code is 0277-786X/14/\$18.00.

Printed in the United States of America.

Paper Numbering: Proceedings of SPIE follow an e-First publication model, with papers published first online and then in print and on CD-ROM. Papers are published as they are submitted and meet publication criteria. A unique, consistent, permanent citation identifier (CID) number is assigned to each article at the time of the first publication. Utilization of CIDs allows articles to be fully citable as soon as they are published online, and connects the same identifier to all online, print, and electronic versions of the publication. SPIE uses a six-digit CID article numbering system in which:

- The first four digits correspond to the SPIE volume number.

- The last two digits indicate publication order within the volume using a Base 36 numbering

system employing both numerals and letters. These two-number sets start with 00, 01, 02, 03, 04, $05,06,07,08,09,0 A, 0 B \ldots$. OZ, followed by 10-1Z, 20-2Z, etc.

The CID Number appears on each page of the manuscript. The complete citation is used on the first page, and an abbreviated version on subsequent pages. Numbers in the index correspond to the last two digits of the six-digit CID Number. 


\section{Contents}

$\checkmark$ Conference Committee

\section{SESSION 1 VIDEO PROCESSING AND COMPRESSION I}

902902 An all-zero blocks early detection method for high-efficiency video coding [9029-1]

Z. Lv, S. Dong, R. Wang, X. Xie, H. Jia, W. Wang, W. Gao, Peking Univ. (China)

902903 Low-cost multi-hypothesis motion compensation for video coding [9029-2]

L. Chen, S. Dong, R. Wang, Z. Wang, S. Ma, W. Wang, W. Gao, Peking Univ. (China)

902904 An optimized template matching approach to intra coding in video/image compression [9029-3]

H. Su, J. Han, Y. Xu, Google Inc. (United States)

902905 Motion estimation optimization tools for the emerging high efficiency video coding (HEVC) [9029-4]

A. Abdelazim, W. Masri, B. Noaman, The American Univ. of the Middle East (Kuwait)

\section{SESSION 2 VIDEO PROCESSING AND COMPRESSION II}

902907 Backwards compatible high dynamic range video compression [9029-6]

V. Dolzhenko, V. Chesnokov, Apical Imaging Ltd. (United Kingdom); E. A. Edirisinghe, Loughborough Univ. (United Kingdom)

902908 Role-based adaptation for video conferencing in healthcare applications [9029-7]

O. Figuerola, H. Kalva, A. Escudero, A. Agarwal, Florida Atlantic Univ. (United States)

\section{SESSION 3 IMAGE PROCESSING}

9029 OA A novel error metric for parametric fitting of point spread functions [9029-9]

J. D. Simpkins, R. L. Stevenson, Univ. of Notre Dame (United States)

9029 OB Joint deblurring and demosaicking of CFA image data with motion blur [9029-10]

R. Zhen, R. L. Stevenson, Univ. of Notre Dame (United States)

9029 OC Parametric phase information based 2D Cepstrum PSF estimation method for blind de-convolution of ultrasound imaging [9029-11]

J. Kang, S.-C. Park, J.-H. Kim, J. Song, Samsung Advanced Institute of Technology

(Korea, Republic of)

9029 OD Dual tree complex wavelet transform based shadow detection and removal from moving objects [9029-12]

M. Khare, R. K. Srivastava, A. Khare, Univ. of Allahabad (India) 
9029 OE Recognition combined human pose tracking using single depth images [9029-13] W. Kim, B. I. Yoo, J.-J. Han, C. Choi, Samsung Advanced Institute of Technology (Korea, Republic of)

9029 OF Video-based facial discomfort analysis for infants [9029-14]

E. Fotiadou, S. Zinger, Technische Univ. Eindhoven (Netherlands); W. E. Tjon a Ten, Maxima Medical Ctr. (Netherlands); S. Bambang Oetomo, Technische Univ. Eindhoven

(Netherlands) and Maxima Medical Ctr. (Netherlands); P. H. N. de With, Technische Univ. Eindhoven (Netherlands)

9029 OG Onomatopoeia characters extraction from comic images using constrained Delaunay triangulation [9029-15]

X. Liu, K. Shoji, H. Mori, F. Toyama, Utsunomiya Univ. (Japan)

$9029 \mathrm{OH} \quad$ Improved global-sampling matting using sequential pair-selection strategy [9029-16]

A. Al-Kabbany, E. Dubois, Univ. of Ottawa (Canada)

SESSION 5 HETEROGENEOUS COMPUTING SYSTEMS FOR HIGH-PERFORMANCE AND LOW-POWER SIGNAL PROCESSING I

$9029 \mathrm{OL}$ Heterogeneous compute in computer vision: OpenCL in OpenCV (Invited Paper) [9029-20]

H. Gasparakis, Advanced Micro Devices (United States)

Author Index

iv 


\section{Conference Committee}

Symposium Chair

Sergio R. Goma, Qualcomm Inc. (United States)

Symposium Co-chair

Sheila S. Hemami, Northeastern University (United States)

Conference Chairs

Amir Said, LG Electronics MobileComm U.S.A., Inc. (United States)

Onur G. Guleryuz, LG Electronics MobileComm U.S.A., Inc.

(United States)

Robert L. Stevenson, University of Notre Dame (United States)

Conference Program Committee

John G. Apostolopoulos, Hewlett-Packard Laboratories

(United States)

Vasudev Bhaskaran, Qualcomm Inc. (United States)

Mireille Boutin, Purdue University (United States)

Chang Wen Chen, University at Buffalo (United States)

Gerard de Haan, Philips Research Nederland B.V. (Netherlands)

Edward J. Delp III, Purdue University (United States)

Eric Dubois, University of Ottawa (Canada)

Frederic Dufaux, Telecom ParisTech (France)

Keigo Hirakawa, University of Dayton (United States)

Marta Karczewicz, Qualcomm Inc. (United States)

Lisimachos Paul Kondi, University of loannina (Greece)

Janusz Konrad, Boston University (United States)

Chun-Chieh Jay Kuo, The University of Southern California (United States)

Peyman Milanfar, University of California, Santa Cruz (United States)

Antonio Ortega, The University of Southern California (United States)

Thrasyvoulos N. Pappas, Northwestern University (United States)

William A. Pearlman, Rensselaer Polytechnic Institute (United States)

Fernando Pereira, Instituto de Telecomunicações (Portugal)

Béatrice Pesquet-Popescu, Telecom ParisTech (France)

Majid Rabbani, Eastman Kodak Company (United States)

Eli Saber, Rochester Institute of Technology (United States)

Dan Schonfeld, University of Illinois at Chicago (United States)

Andrew Segall, Sharp Laboratories of America, Inc. (United States)

Gaurav Sharma, University of Rochester (United States) 
Andrew G. Tescher, AGT Associates (United States)

Anthony Vetro, Mitsubishi Electric Research Laboratories

(United States)

John W. Woods, Rensselaer Polytechnic Institute (United States)

Wenwu Zhu, Tsinghua University (China)

\section{Session Chairs}

1 Video Processing and Compression I

Amir Said, LG Electronics MobileComm U.S.A., Inc. (United States)

Onur G. Guleryuz, LG Electronics MobileComm U.S.A., Inc.

(United States)

Robert L. Stevenson, University of Notre Dame (United States)

2 Video Processing and Compression II

Amir Said, LG Electronics MobileComm U.S.A., Inc. (United States)

Onur G. Guleryuz, LG Electronics MobileComm U.S.A., Inc.

(United States)

Robert L. Stevenson, University of Notre Dame (United States)

3 Image Processing

Amir Said, LG Electronics MobileComm U.S.A., Inc. (United States)

Onur G. Guleryuz, LG Electronics MobileComm U.S.A., Inc.

(United States)

Robert L. Stevenson, University of Notre Dame (United States)

4 Computer Vision

Amir Said, LG Electronics MobileComm U.S.A., Inc. (United States)

Onur G. Guleryuz, LG Electronics MobileComm U.S.A., Inc.

(United States)

Robert L. Stevenson, University of Notre Dame (United States)

5 Heterogeneous Computing Systems for High-Performance and Low-Power Signal Processing I

Michael Frank, LG Electronics Inc. (United States)

Shereef Shehata, LG Electronics Inc. (United States) 